\title{
Infectious events in kidney transplant recipients from deceased expanded criteria donors: a prospective cohort
}

\author{
Eventos infecciosos em receptores de transplante renal de doador falecido com critério \\ expandido: coorte prospectiva \\ Eventos infecciosos en receptores de trasplante renal de donante fallecido con criterios \\ expandidos: cohorte prospectiva
}

How to cite this article:

Sousa SR, Fonseca CD, Taminato M, Vattimo MFF, Belasco AGS, Sousa AFL, Fronteira I, Barbosa DA. Infectious events in kidney transplant recipients from deceased expanded criteria donors: a prospective cohort. Rev Esc Enferm USP. 2021;55:e20210255. DOI: https://doi.org/10.1590/1980-220X-REEUSP-2021-0255.

Sirlei Regina de Sousa ${ }^{1}$

Cassiane Dezoti da Fonseca ${ }^{1}$

Monica Taminato ${ }^{1}$

(D) Maria de Fatima Fernandes Vattimo $^{2}$

Angélica Gonçalves Silva Belasco ${ }^{1}$

D Álvaro Francisco Lopes de Sousa ${ }^{3}$

D) Inês Fronteira ${ }^{3}$

Dulce Aparecida Barbosa ${ }^{1}$

${ }^{1}$ Universidade Federal de São Paulo,

Departamento de Saúde Coletiva, Escola

Paulista de Enfermagem, São Paulo, SP, Brazil.

${ }^{2}$ Universidade de São Paulo, Escola de

Enfermagem, Departamento de Saúde

Coletiva, São Paulo, SP, Brazil.

${ }^{3}$ Global Health and Tropical Medicine,

Instituto de Higiene e Medicina Tropical,

Universidade Nova de Lisboa, Lisboa, Portugal.

\begin{abstract}
Objective: Analyze risk factors for infection in kidney transplant recipients from deceased expanded criteria donors (DECD) in the first two years of follow-up. Method: This is a prospective cohort study with 466 patients from DECD who underwent kidney transplantation in 2015 and 2016 in Brazil. A total of 551 events were recorded. The largest incidence of infectious events occurred in the first month after kidney transplantation. Cytomegalovirus infection was the most common infectious episode. Results: The incidence rate of infections was $57.1 \%$. Among bacterial infections, only $4 \%$ were due to multidrug-resistant microorganisms. The death rate was 3.3\% (15) patients. The main cause of death was infectious (73.3\%). Hospitalization until the first infection (aOR:1.61), Number of infections in 1 year (aOR:40.16), and Cytomegalovirus infection (aOR:13.84) was risk factors for infection by multidrug resistant microorganisms (MDR). Conclusion: Infection incidence with MDR bacteria was high among kidney transplant recipients from DECD, and the main cause of death was infection. Survival was high among patients with infection.
\end{abstract}

\section{DESCRIPTORS}

Infections; Kidney Transplantation; Transplants; Mortality; Survival rate.

Corresponding author:

Álvaro Francisco Lopes de Sousa

Avenida dos Bandeirantes, 3900

Bairro Monte Alegre

14040-902, Ribeirão Preto, SP, Brazil

sousa.alvaromd@gmail.com 


\section{INTRODUCTION}

Kidney transplant accounts for the largest share of all solid organ transplants in the world. Quality of life and survival rates in kidney transplantation have been improving mainly due to improvement in surgical techniques, immunosuppressive therapy and better clinical management of these patients ${ }^{(1)}$.

In Brazil, the rate of kidney transplantation between 2012 and 2018 remained unchanged (28.5 pmp), with a drop of $32.9 \%$ in the rate of transplants from live donors, from $7.3 \mathrm{pmp}$ to $4.9 \mathrm{pmp}$ and an increase in the rate of transplantation from deceased donors of only $10.3 \%$ (from $21.4 \mathrm{pmp}$ to $23.6 \mathrm{pmp}$ ). In 2018 the rate of effective donors grew by only $2.4 \%$, from $16.6 \mathrm{pmp}$ in 2017 to $17.0 \mathrm{pmp}$ in $2018,5.5 \%$ below the expected rate (18.0 pmp). This increase was due to a $0.6 \%$ increase in the notification rate of potential donors and $2.2 \%$ increase in the donation effectiveness rate. However, the growth rate of organ transplantation with deceased donors was only $0.7 \%$, from $41.0 \mathrm{pmp}$ to $41.3 \mathrm{pmp}$, revealing an increase in the rate of non-use of deceased donor organs. In 2018, 4,905 transplants were performed with a deceased donor with a survival rate of $83 \%$ in the first year after transplantation ${ }^{(1-2)}$.

As a consequence of the imbalance between the number of transplants and the waiting list, the number of deaths and patients on the list grows, registering a lower quality of life, worse rehabilitation and increased costs after a transplant. To minimize this problem and increase the number of organs for kidney transplantation, it has been proposed to use borderline or expanded criteria donors. Deceased donors are considered donors who provide organs for transplantation that offer greater risk to recipients or risk of worse graft functioning in the long term ${ }^{(2-3)}$. Expanded criteria donors ${ }^{(3)}$ are donors over 60 or between 50 and 59 years old (with at least 2 of the 3 criteria: being hypertensive, having creatinine level greater than $1.5 \mathrm{mg} / \mathrm{dl}$, having stroke as the cause of death), kidney and diabetic donors, pediatric donors, borderline donors as to the potential for disease transmission and the presence of malignant abnormalities, donors with infection, donors with social/sexual behavior with inclusion in risk groups, and donors with kidneys with anatomical abnormalities.

For deceased donor recipients, selection is based on blood group compatibility (ABO), HLA and negative cross-testing. Studies that analyze survival, morbidity and mortality in kidney transplant recipients are important to also assess the cause of death in this group of patients. The leading cause of death during the first year of transplantation has an infectious etiology $y^{(4-6)}$.

Infectious events are often related to two conditions: patient immunosuppression and environmental exposures ${ }^{(2,5-7)}$. In kidney transplant patients, the rate of infectious events is $49 \%$, and these complications add significant morbidity and mortality for patients, especially in the first year after transplantation ${ }^{(8)}$.

Infection remains the major cause of morbidity and the second most frequent cause of mortality, preceded only by cardiovascular events as the first cause of death for patients with $\mathrm{CKD}^{(9-12)}$.
Based on the risk of bacterial colonization and infection of kidney deceased expanded criteria donors (DECD) and on the need for additional epidemiological studies on morbidity and mortality of DECD, we conducted a study to analyze risk factors for infection in kidney transplant recipients from DECD in the first two years of follow-up.

\section{METHODS}

\section{Type OF Study}

This is a prospective cohort study ${ }^{(13)}$ of kidney transplant DECD recipients who underwent transplantation at Oswaldo Ramos Foundation's Kidney and Hypertension Hospital in the city of São Paulo, Brazil.

The Kidney and Hypertension Hospital (HRIM Hospital do Rim e Hypertension) is a world reference in kidney transplantation, internationally recognized for the quality of care, teaching and research, with an average of 1,000 transplants per year.

\section{Population; local; Selection Criteria}

The study comprised the 466 patients from DECD who underwent kidney transplantation in 2015 and 2016. Patients with 18 years or older, of both sexes, who underwent transplantation from DECD and with completeness of data in the medical record were included.

\section{Data Collection}

Data collection was performed by two research nurses, specialists in nephrology, using the patients' records. A double check was performed on the data entered in the spreadsheet as well as an audit to confirm data tabulation. The variables collected were sociodemographic, clinical, biochemical, type of immunosuppressants, need for post-transplant dialysis treatment, site and type of infection confirmed by culture, graft loss, cause of graft loss, death, and cause of death.

In relation to DECD, data was collected on age, weight and height (BMI), race, blood type, cause of death, initial and final creatinine value, use of vasoactive drugs, presence of cardiac arrest (CPR), presence of infection, etiologic agent, infection site, use of antibiotics, recipient serology, and presence of acute tubular necrosis (ATN).

The presence and type of infection, late infection (type of infection up to 24 months) after transplantation were verified. The identification of all types of infectious events (urinary tract infection, surgical site, pulmonary and bloodstream) was based on the description of signs and symptoms, medical diagnosis, and positive laboratory exams, as registered in the medical records.

Cytomegalovirus (CMV) infection was defined by signs and symptoms and, mainly, by the result of antigenemia described by a peripheral blood sample or in biopsies. The presence of herpes zoster infections was defined according to the description of the lesions and site. Pulmonary infections were defined according to signs and symptoms, description 
of fever, cough, exams compatible with the diagnosis (radiography, result of bronchial aspirate).

For each infection site, the medical record was assessed by a medical professional, with results of tests that confirmed the type of etiologic agent and bacterial multidrug resistance as well as the proposed treatment and outcome of the case. The delayed function of the graft was considered whenever renal replacement therapy in the first week after kidney transplantation with deceased donors took place.

Regarding the type of deceased donor, DECD (borderline) were classified as donors 60 years of age or older, with creatinine above $1.5 \mathrm{mg} / \mathrm{dl}$, with brain death, hemorrhagic stroke, CRP documented, presence of infection or in the course of infection treatment.

\section{Data Analysis and Treatment}

In the descriptive analysis, data were presented using counts and frequencies, means, standard deviations, and minimum and maximum values, when appropriate. In order to identify possible risk factors for the onset of infections, the isolated influence of each variable was initially investigated.

Pearson's chi-square test or Fisher's exact test was used to compare the number of patients with and without infections for the different categorical variables. The Mann-Whitney or Student's t test was used for quantitative variables to compare the group with and without infection ${ }^{(14)}$. The same was done to ascertain the characteristics associated with infection by multidrug resistant (MDR) bacteria to some infection data.

Variables with $\mathrm{p}<0.05$ in the univariate analysis were included in a multiple logistic regression model (multivariate approach). The results were presented as Odds Ratio, respective descriptive levels ( $p$ values) and 95\% confidence intervals. The reduced model corresponds to the final model, with all significant covariables at 5\%.

Weibull model of survival was used for variables whose survival curve was different for the different groups to ascertain the variables associated with the time until the first infection $^{(14)}$. The level of significance adopted was 0.05 . The statistical program used to perform the calculations was RStudio, version 1.2.1335 and $\mathrm{R}$, version 3.4.4.

\section{Ethical Aspects}

The research was analyzed and approved in 2016 by the Ethics Committee of the Federal University of São Paulo, with Opinion Number: 1,777,351; as required by Brazilian resolution 466/12. Since the research worked only with secondary data, there were no direct ethical implications for the participants.

\section{RESULTS}

We analyzed the medical records of 466 recipients from DECD under follow-up, followed for two years at the transplant clinic. Table 1 presents the demographic characteristics of kidney recipients and DECD.

Table 2 shows kidney transplant characteristics of the 466 kidney transplant recipients from DECD and immunosuppression protocol.
Table 1 - Characteristics prior to transplantation of kidney recipients and deceased expanded criteria donors - São Paulo, SP, Brazil.

\begin{tabular}{lcc}
\hline Characteristics & Recipient & Donor \\
\hline Male & $294(63.1 \%)$ & \\
Female & $172(36.9 \%)$ & \\
Age, mean (SD) & $47.01(12.1)$ & $46.86(14.0)$ \\
BMI, mean (SD) & $24.40(4.6)$ & $26.25(5.6)$ \\
\hline Blood type & & \\
A & $193(41.4 \%)$ & $186(39.9 \%)$ \\
B & $58(12.4 \%)$ & $48(10.3 \%)$ \\
O & $183(39.3 \%)$ & $184(39.5 \%)$ \\
AB & $28(6.0 \%)$ & $27(5.8 \%)$ \\
\hline Serology & & \\
Negative & $51(11.0 \%)$ & $297(63.7 \%)$ \\
CMV & $370(79.2 \%)$ & $169(36.3 \%)$ \\
Others & $45(9.6 \%)$ & \\
\hline
\end{tabular}

\section{Alcoholic}

$\begin{array}{cc}\text { Yes } & 42(9.0 \%) \\ \text { No } & 424(91.0 \%)\end{array}$

\section{Former smoker}

$\begin{array}{ll}\text { Yes } & 140(30.0 \%) \\ \text { No } & 326(70.0 \%)\end{array}$

\begin{tabular}{lc}
\hline Hematocrit mean (SD) & $39.6(18.9)$ \\
Hemoglobin mean (SD) & $13.0(4.2)$ \\
Leukocytes mean (SD) & $7731.90(6758.8)$ \\
Platelets mean (SD) & $205.59(72876.9)$ \\
PTH* mean (SD) & $581.40(524.9)$ \\
Diuresis in 24h mean (SD) & $583.30(459.1)$
\end{tabular}

*SD - Standard deviation; BMI - Body Mass Index; CMV - Cytomegalovirus; PTH - Parathyroid hormone.

The average age of donors was 46.8 years. All donors had negative serology for hepatitis $\mathrm{B}, \mathrm{C}$ and HIV. For CMV positive serology, a total of $169(36.3 \%)$ were positive. The initial and final donor creatinine values ranged from 1.1 to $2.3 \mathrm{mg} / \mathrm{dl}$. Regarding race, $49.1 \%$ of donors were registered as white race and $33.3 \%$ as mixed race. For blood type, $39.9 \%$ had blood type A and 39.5\%, type O. Only 3.9\% of the donors had PCR before the actual organ donation. At the time of identification of the donor, $13.1 \%$ had some type of infection under treatment. For the result of the donor kidney biopsy in relation to the presence of ATN, it was classified as mild for $21.1 \%$ of the biopsies, moderate for $35.8 \%$ and severe for $7.3 \%$. The main cause of death of the donor was stroke (31.5\%), followed by AVI (14.4\%). The use of vasoactive drugs (noraepinephrine) was present in $88.6 \%$.

Regarding the survival analysis, it is noted that in the group without infection, the survival time to discharge is 1 and does not change over time, indicating that no one in this group died. In the group with infection, on the other hand, the survival time until discharge decreases over time, indicating that the number of survivors decreases over time (Part B). For part A of the figure, it is noted that the survival time until discharge decreases over time and that there are several censors over time, indicating that several of them did not suffer the event (Figure 1). 
Table 2 - Characteristics of kidney transplantation and immunosuppression protocol - São Paulo, SP, Brazil.

\begin{tabular}{lc}
\hline Characteristics & n (\%)/mean \\
\hline Cold ischemia time (minutes) - mean (SD) & $1,503(400.1)$ \\
Vascular anastomosis time (minutes) - mean (SD) & $30(9.5)$ \\
\hline Type of urethral anastomosis & \\
Gregoir & $249(53.4 \%)$ \\
Politano & $144(31 \%)$ \\
U-P & $57(12.2 \%)$ \\
Delay bladder catheter time (days) - mean (SD) & $5.9(1.7)$ \\
Total RRT after transplantation, mean (SD) & $3.5(2.6)$ \\
Discharge in days after transplantation, mean (SD) & $13.3(10.7)$ \\
FPM & $220(47.2 \%)$ \\
FP & $46(9.9 \%)$ \\
Everolimus & $31(6.6 \%)$ \\
Simulect & $16(3.4 \%)$ \\
\hline Thymoglobulin use & \\
Once & $186(39.9 \%)$ \\
Twice & $33(7.1 \%)$ \\
Three times & $23(4.9 \%)$ \\
Four times & $74(15.9 \%)$ \\
Five times & $41(8.8 \%)$ \\
PRA C I & $40.5(42.3)$ \\
PRA C II & $51.5(26.1)$ \\
\hline
\end{tabular}

*U-P: Pyeloureteral anastomosis; RRT - Renal Replacement Therapy; FPA Tacrolimus (FK), Prednisone and Azathioprine; FPM - Tacrolimus, Prednisone and Mycophenolate Sodium; FP - Tacrolimus and Prednisone; PRA - PanelReactive Antibody.
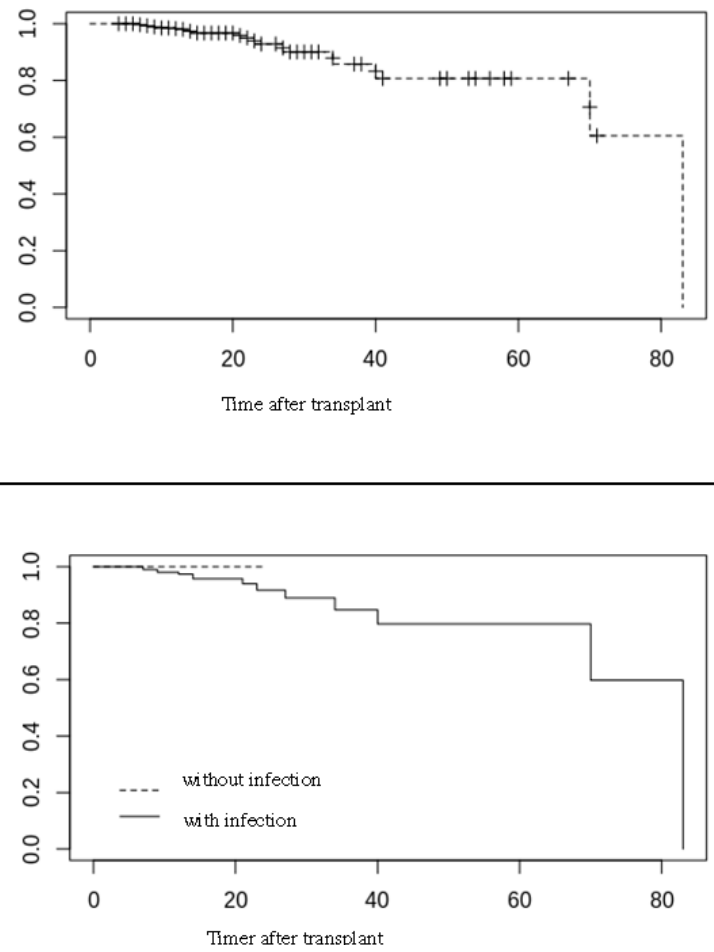

Figure 1 - Survival curves among kidney transplant recipients with and without infectious episodes.

The largest incidence of infectious events occurred in the first month after kidney transplantation. A total of 551 events were recorded. CMV infection was the most common infectious episode. The incidence rate of infections was $57.1 \%$. Among bacterial infections, only $4 \%$ were due to multidrug-resistant microorganisms. CMV infections occurred mainly from the first to the third month (281/81\%). Then, urinary tract infections (UTIs) were the most present. In the second year after transplantation, a total of 27 episodes of infectious (flu, tonsillitis, dengue, among others) were observed). The most frequent etiologic agents in the result of urine cultures from 123 UTI were Escherichia coli (31 urine cultures), Klebsiella (19 urine cultures) and Klebsiella Pneumoniae Carbapenemase (KPC). For other infections, 14 pneumonias, 10 bloodstream infections, 15 surgical site infections, nine herpes zoster, seven genital herpes and several others were observed. In the period from the thirteenth to the twenty-fourth month after transplantation, there were only 27 different infectious events.

Table 3 presents a comparison between kidney transplant recipients from DECD with and without infection. The death rate was 3.3\% (15) patients. The main cause of death was infectious (73.3\%), followed by cardiovascular (26.6\%) and hemorrhagic shock (0.01\%). All recipients who died had an infectious event after transplantation, with $80 \%$ having CMV infection.

The risk factors for infection of recipients in univariate analysis were time on dialysis in months, positive serology for CMV, type of urethral anastomosis UP, post-transplant RRT, use of the immunosuppressive protocol FPA, FPM,

Table 3 - Presence of infection in kidney transplant recipients São Paulo, SP, Brazil.

\begin{tabular}{|c|c|c|c|}
\hline Total patients & With infection & $\begin{array}{l}\text { Without } \\
\text { infection }\end{array}$ & $p$ value \\
\hline Recipient & $327(70.2 \%)$ & $139(29.8 \%)$ & \\
\hline $\begin{array}{l}\text { Sex, } \mathrm{n} \% \\
\text { Female }\end{array}$ & $128(39.1 \%)$ & $44(31.6 \%)$ & 0.1253 \\
\hline Male & $199(60.9 \%)$ & $95(68.4 \%)$ & \\
\hline BMI & $24.6(4.9)$ & 23.77 (3.9) & 0.0259 \\
\hline \multicolumn{4}{|l|}{ Race } \\
\hline White & $95(29.1 \%)$ & $38(27.3 \%)$ & \multirow{4}{*}{0.8894} \\
\hline Black & $69(21.1 \%)$ & $29(20.8 \%)$ & \\
\hline Brown & $144(44.0 \%)$ & $62(44.6 \%)$ & \\
\hline Yellow & $10(3.1 \%)$ & $6(4.3 \%)$ & \\
\hline \multicolumn{4}{|l|}{ CKD etiology* } \\
\hline Undetermined & $142(43.4 \%)$ & $59(42.4 \%)$ & \multirow{7}{*}{0.8169} \\
\hline Diabetes & $47(14.4 \%)$ & $17(12.2 \%)$ & \\
\hline Hypertension & $47(14.4 \%)$ & $28(20.1 \%)$ & \\
\hline $\begin{array}{l}\text { Diabetes and } \\
\text { hypertension }\end{array}$ & $9(2.7 \%)$ & $3(2.2 \%)$ & \\
\hline PKD* & $24(7.3 \%)$ & $11(7.9 \%)$ & \\
\hline Glomerulopatias & $30(9.2 \%)$ & $12(8.6 \%)$ & \\
\hline Others & $28(8.6 \%)$ & $9(6.4 \%)$ & \\
\hline \multicolumn{3}{|l|}{ Transfusion } & 0.18 \\
\hline No transfusion & $141(43.1 \%)$ & $63(45.3 \%)$ & \\
\hline $\begin{array}{l}\text { Received up to } \\
5 \text { bags }\end{array}$ & $163(49.8 \%)$ & $68(48.9 \%)$ & 0.8333 \\
\hline Above 5 bags & $23(7.0 \%)$ & $8(5.7 \%)$ & \\
\hline
\end{tabular}

continue... 
...continuation

\begin{tabular}{|c|c|c|c|}
\hline Total patients & With infection & $\begin{array}{l}\text { Without } \\
\text { infection }\end{array}$ & $p$ value \\
\hline \multicolumn{4}{|l|}{ Pre-transplant tests } \\
\hline PTH & $576.4(522.0)$ & $593.4(534.0)$ & 0.3635 \\
\hline Hemoglobin & $13.1(4.8)$ & $12.7(1.9)$ & 0.3611 \\
\hline Hematocrit & $40.2(22.2)$ & $38.2(6.2)$ & 0.5784 \\
\hline Leukocytes & $7,636(5,400.9)$ & $7,954(9,195.2)$ & 0.5067 \\
\hline Platelets & $\begin{array}{l}207,714 \\
(76,755)\end{array}$ & $\begin{array}{l}200,724 \\
(63,029)\end{array}$ & 0.3455 \\
\hline $\begin{array}{l}\text { Priority for } \\
\text { transplant }\end{array}$ & $313(95.7)$ & $134(96.4)$ & \\
\hline Post-transplant RRT & $2.4(2.9)$ & $1.3(1.7)$ & 0.7104 \\
\hline \multicolumn{4}{|l|}{ Immunosuppression } \\
\hline FPA (yes) & $98(29.9 \%)$ & $78(56.5 \%)$ & \multirow[t]{2}{*}{$6.082 \times 10-8$} \\
\hline FPA (no) & $230(70.1 \%)$ & $60(43.5 \%)$ & \\
\hline FPM (yes) & $193(58.8 \%)$ & $42(30.4 \%)$ & \multirow{2}{*}{$2.15 \times 10-8$} \\
\hline FPM (no) & $135(41.2 \%)$ & $96(69.6 \%)$ & \\
\hline FP (yes) & $34(10.4 \%)$ & $16(11.6 \%)$ & \multirow{2}{*}{0.6957} \\
\hline $\mathrm{FP}(\mathrm{no})$ & $294(89.6 \%)$ & $122(88.4 \%)$ & \\
\hline Everolimus & $22(6.7 \%)$ & $10(7.2 \%)$ & \multirow{2}{*}{0.7965} \\
\hline Simulect & $11(3.4 \%)$ & $5(3.7 \%)$ & \\
\hline \multicolumn{4}{|l|}{ Thymoglobulin use } \\
\hline No & $58(17.7 \%)$ & $56(40.3 \%)$ & \\
\hline Once & $124(37.9 \%)$ & $59(42.4 \%)$ & \\
\hline Twice & $23(7 \%)$ & $7(5 \%)$ & \\
\hline Three times & $22(6.7 \%)$ & $1(0.7 \%)$ & \\
\hline Four times & $65(19.8 \%)$ & $9(6.5 \%)$ & \\
\hline Five times & $35(10.7 \%)$ & $7(5 \%)$ & \\
\hline CMV infection & $241(73.7 \%)$ & $2(1.4 \%)$ & \multirow{2}{*}{$<0.001$} \\
\hline No CMV infection & $86(26.3 \%)$ & $137(98.5 \%)$ & \\
\hline Recipient death & $15(4.6 \%)$ & $0(0.0 \%)$ & 0.0075 \\
\hline
\end{tabular}

*BMI - Body Mass Index; CKD - Chronic Kidney Disease; PKD - Polycystic Kidney Disease; FPA - Tacrolimus, Prednisone, Azathioprine; FPM Tacrolimus, Prednisone, Mycophenolate; FP - Tacrolimus and Prednisone; CMV - Cytomegalovirus.

induction with thymoglobulin and presence of infection by $\mathrm{CMV}$. The presence of CMV infection increases the chance by almost 14 times to have post-transplant infection.

Table 4 presents the multivariate analysis for risk factors of infection among kidney transplant recipients. The variables associated with post-transplant infection were length of hospitalization (average of 13.3 days and $10.7 \mathrm{SD}$ ) until the first infection, number of infections (average of 1.68 infections and 1.1 SD) in one year and CMV infection. Every increase of one unit in days until the first infection increases the chance of having an infection by $0.6 \%$. The presence of $\mathrm{CMV}$ infection increases the chances of having post-transplant infection by almost 14 times. The risk factors for infection for the $327(70.2 \%)$ recipients were the use of the immunosuppressive protocol FPA, FPM, induction with thymo and presence of CMV infection. The presence of CMV infection increases the chance of another infection 15.5 times.

The presence of infection by MDR microorganisms was observed in 20 (6.1\%) of kidney transplant recipients from DECD. The risk factors for infection by MDR microorganisms were history of diabetes $(7.2[1.4 ; 30.6])$. The most
Table 4 - Multivariate analysis for risk factors for infection among kidney transplant recipients - São Paulo, SP, Brazil.

\begin{tabular}{lccc}
\hline Variables & Odds ratio & $\mathbf{9 5} \% \mathbf{C l}$ & P value \\
\hline Time on dialysis & 0.98 & {$[0.96 ; 1.01]$} & 0.3271 \\
$\begin{array}{l}\text { Positive serology } \\
\text { Container - CMV }\end{array}$ & 0.46 & {$[0.03 ; 5.95]$} & 0.5382 \\
$\begin{array}{l}\text { Type of urethral } \\
\text { anastomosis U-P }\end{array}$ & 17.78 & {$[0.11 ; 19.16]$} & 0.6588 \\
RRT after transplant & 0.85 & {$[0.46 ; 1.56]$} & 0.6170 \\
RRT-DFG indication & 33.25 & {$[0.47 ; 31.56]$} & 0.2711 \\
FPA use & 62.43 & {$[0.31 ; 166.76]$} & 0.2532 \\
FPM use & 29.18 & {$[0.16 ; 63.08]$} & 0.4728 \\
Discharge on post- & 10.20 & {$[0.93 ; 1.21]$} & 0.7414 \\
transplant days & 16.26 & {$[1.38 ; 317.52]$} & 0.0403 \\
CMV infection & 18.17 & {$[0.29 ; 11.72]$} & 0.5136 \\
Thymo 1 time & 15.65 & {$[0.05 ; 35.12]$} & 0.7825 \\
Thymo 2 times & 23.10 & {$[0.02 ; 587.44]$} & 0.7919 \\
Thymo 3 times & 57.12 & {$[0.11 ; 253.01]$} & 0.3745 \\
Thymo 4 times & 84.49 & {$[0.15 ; 464.91]$} & 0.3097 \\
Thymo 5 times & 10.84 & {$[1.12 ; 1.19]$} & 0.0538 \\
Recipient age & 10.22 & {$[0.95 ; 1.09]$} & 0.5174 \\
Donor age & & & \\
\hline Results - Multivariate analysis - model reduced & \\
Hospitalization until & 1.61 & {$[1.16 ; 1.72]$} & 0.0064 \\
the first infection & & & \\
Number of infections & 40.16 & {$[102.06 ; 27.84]$} & $<0.001$ \\
in 1 year & 13.84 & {$[1.96 ; 127.17]$} & 0.0106 \\
CMV infection & & & \\
\hline & & & \\
\hline
\end{tabular}

common infection was UTI (70.0\%), and the etiologic agent $\mathrm{KPC}$ was diagnosed in eleven urine cultures (78.5\%). KPC pneumonia was present in four patients and in one due to surgical site infection (SSI). One patient had an UTI for Escherichia coli MDR, a SSI for VRE, and two had KPC and Escherichia coli. Three patients died, two due to infectious causes, only one during the 93-day period during hospitalization and being treated for infection. The other two deaths occurred after one year of transplantation. The patient with Vancomycin-resistant Enterococcus (VRE) infection in SSI had graft loss 26 days after transplantation. The two recipients who received transplants from donors with KPC and Klebsiella developed KPC infection.

\section{DISCUSSION}

In this study, 466 kidney recipients from DECD who underwent transplantation from January 2015 to December 2016 were followed up for three years. DECD use has increased due to the disproportion between the waiting list and the accomplishment of transplantation annually ${ }^{(15)}$ as well as due to the mortality of patients under renal replacement therapy $(19.5 \%)^{(2)}$.

In this study, infection incidence was $70.2 \%$, accounting for 551 episodes of infections. Infection incidence in kidney transplant recipients was more present in the first few months after transplantation. The most common infections are CMV and UTI. A systematic literature review with criteria for inclusion of articles, assessing the outcome of the presence of infection and type of donor, found that kidney 
recipients from a deceased donor present a $20 \%$ higher risk of developing infections ${ }^{(16)}$.

Our study identified that CMV infection was the most prevalent infectious episode and occurred mainly from the first to the third month (281/81\%). CMV infection is an important cause of morbidity and mortality in kidney transplantation. The donor's serological status was identified as an influential factor for CMV infection $(p=0.0320)$. In this study, $52.1 \%$ of kidney transplant recipients had CMV infection. The episode was more frequent in the first 30 days after transplantation. Of the 20 recipients with MDR infection, 12 had CMV infection. All recipients had positive CMV serology. A different result regarding the time of occurrence of CMV infection was observed in a study with a cohort of 5,225 kidney transplant recipients who underwent the transplant from 1994 to 2014; the occurrence of CMV infection in the first 30 days was $0.2 \%$. Antiviral therapy for $\mathrm{CMV}$ was introduced within 72 hours after kidney transplantation ${ }^{(17)}$.

The presence of diabetes in kidney transplant recipients was considered a risk factor for infection ${ }^{(18-20)}$. A retrospective case-control study was carried out to identify independent risk factors for Escherichia coli and Klebsiella pneumoniae producing extended-spectrum beta-lactamases (ESBL) in kidney transplant recipients in Portugal under outpatient follow-up ${ }^{(18)}$. Thus, 49 patients with UTI were compared by ESBL-producing bacteria as a group of cases and the same number of patients with UTI by negative ESBL as a control group. The presence of diabetes mellitus $(p<0.007)$ represented a risk factor for infection by ESBL-producing bacteria. ESBL-producing bacteria exhibited greater resistance to fluoroquinolones $(\mathrm{p}=0.002)$, trimethoprim-sulfamethoxazole $(p<0.001)$, and gentamicin $(p<0.001)$. ESBL-producing UTI in ESBL recipients in kidney transplant recipients represents an important clinical challenge not only in hospitalized patients, but also in outpatients ${ }^{(21-22)}$.

Only one case of positive urine culture for Escherichia coli MDR was observed in our study. Of the total of 123 UTI, 31 (25\%) had positive urine culture for Escherichia coli. The clinical history and immunocompromised status of kidney transplant recipients allows strains of Escherichia coli with low uropathogenic potential, but with greater resistance to antibiotics, to cause $\mathrm{UTI}^{(21-24)}$.
Immunosuppression use was predominant for FPA (37.8\%) and FPM (50.4\%) in our study. There was a six-fold increase in infection in recipients who used FPM and twice in recipients who used FPA. At the Kidney and Hypertension Hospital transplantation clinic, the available presentations for the immunosuppressive regimen are liquid cyclosporin and capsules, azathioprine tablets, tacrolimus capsules, mycophenolate mofetil tablets, MPS tablets, sirolimus in vials and tablets, everolimus tablets and prednisone tablet ${ }^{(25)}$. In our study, no patient used cyclosporine.

In this study, $3.3 \%$ of patients died. Infection was the main cause of mortality (73.3\%). A Brazilian study with a cohort of 1,873 kidney transplant recipients described a total of 162 deaths ( 35 with DECD), with $53 \%$ of deaths due to infectious causes. The risk factors that were related to mortality were diabetes, time on dialysis, length of hospital stay, and others ${ }^{(6)}$. Another study with 944 kidney transplant recipients, who underwent transplantation from 2002 to 2015 , aiming at identifying the cause of death of this group of patients reported that $10.2 \%$ (102) died, $35.5 \%$ due to infectious causes and $30.4 \%$ due to cardiovascular causes $^{(26)}$.

This research has limitations that must be considered. Data collection of information about the donor and the presence or absence of infection was limited to reviewing the records in medical records. However, we know that these records can have flaws related to team activities. The donor's presence in the Intensive Care Unit can favor infections that may not be diagnosed during the donation process. Studies that assess the results of transplantation with expanded donors can contribute to the discussion of public policies that favor the entire transplant system, from donation to the actualization of the transplant.

\section{CONCLUSION}

Risk factors for infection were length of stay, having CMV infection, use of FPM, FPA and induction with thymoglobulin. The risk factor for infection by MDR microorganism was a history of diabetes. Infection incidence with MDR bacteria was high among kidney transplant recipients from DECD, and the main cause of death among kidney transplant recipients with deceased donor was infection. Survival was high among patients with infection.

\section{RESUMO}

Objetivo: Analisar fatores de risco para infecção em receptores de transplante renal de doador falecido com critério expandido (DFCE) nos primeiros dois anos de seguimento. Método: Trata-se de estudo de coorte prospectivo, com 466 pacientes do DFCE submetidos a transplante renal, em 2015 e 2016, no Brasil. Um total de 551 eventos foram registrados. A maior incidência de eventos infecciosos ocorreu no primeiro mês após o transplante renal. A infecção por citomegalovírus foi o episódio infeccioso mais comum. Resultados: A taxa de incidência de infecções foi de 57,1\%. Entre as infecções bacterianas, apenas 4\% foram devidas a microrganismos multirresistentes. A taxa de mortalidade foi de 3,3\% (15) pacientes. A principal causa de morte foi infecciosa (73,3\%). Hospitalização até a primeira infecção (ORa: 1,61), número de infecções em 1 ano (ORa: 40,16) e infecção por citomegalovírus (ORa: 13,84) foram fatores de risco para infecção por microrganismos multirresistentes (MR). Conclusão: A incidência de infecção por bactérias MR foi alta entre receptores de transplante renal de DFCE, e a principal causa de morte foi infecção. A sobrevivência foi alta entre os pacientes com infecção.

\section{DESCRITORES}

Infecções; Transplante de rim; Transplantes; Mortalidade; Taxa de sobrevida. 
RESUMEN

Objetivo: Analizar los factores de riesgo de infección en receptores de trasplante renal de donante fallecido con criterios expandidos (DFCE) en los dos primeros años de seguimiento. Método: Estudio prospectivo de cohorte con 466 pacientes con DFCE sometidos a trasplante renal, en 2015 y 2016, en Brasil. Se registraron un total de 551 eventos. La mayor incidencia de eventos infecciosos ocurrió en el primer mes después del trasplante de riñón. La infección por citomegalovirus fue el episodio infeccioso más común. Resultados: La tasa de incidencia de infecciones fue de157,1\%. Entre las infecciones bacterianas, solo el 4\% se debió a microorganismos multirresistentes. La tasa de mortalidad fue del 3,3\% (15) pacientes. La principal causa de muerte fue infecciosa (73,3\%). La hospitalización hasta la primera infección (ORa: 1,61), el número de infecciones en 1 año (ORa: 40,16) y la infección por citomegalovirus (ORa: 13,84) fueron factores de riesgo de infección por microorganismos multirresistentes (MR). Conclusión: La incidencia de infección bacteriana por MR fue alta entre los receptores de trasplante renal DFCE y la principal causa de muerte fue la infección. La supervivencia fue alta entre los pacientes con infección.

\section{DESCRIPTORES}

Infecciones; Trasplante de Riñón; Trasplantes; Mortalidad; Tasa de Supervivencia.

\section{REFERENCES}

1. Santos FGTD, Mezzavila VAM, Rodrigues TFCDS, Cardoso LCB, Silva MD, Oliveira RR, et al. Trend of transplants and organ and tissue donations in Brazil: a time series analysis. Rev Bras Enferm. 2021;74(1):e20200058. DOI: http://dx.doi.org/10.1590/0034-7167-20200058 .

2. Associação Brasileira de Transplantes de órgãos. Registro Brasileiro de Transplantes. Lisboa: Associação Brasileira de Transplantes de órgãos; 2018. Available from: http://www.abto.org.br/abtov03/Upload/file/RBT/2018/rbt2018-1-populacao.pdf.

3. Olivera LM, Okuno MFP, Barbosa DA, Sesso RCC, Scherrer Júnior G, Pessoa JLE, et al. Quality of life and spirituality of patients with chronic kidney disease: pre- and post-transplant analysis. Rev Bras Enferm. 2020;73(Suppl 5):e20190408. DOI: http://dx.doi.org/10.1590/00347167-2019-0408.

4. Mouelhi Y, Jouve E, Alessandrini M, Pedinielli N, Moal V, Meurette A, et al. Factors associated with Health-Related Quality of Life in Kidney Transplant Recipients in France. BMC Nephrol. 2018;19(1):99. DOI: http://dx.doi.org/10.1186/s12882-018-0893-6.

5. Pessoa JLE, Knihs NDS, Magalhães ALP, Paim SMS, Wachholz LF, Roza BA. Obtaining tissues and organs for transplantation and coronavirus infections: a scoping review. Rev Bras Enferm. 2021;74(Suppl 1):e20200610. DOI: http://dx.doi.org/10.1590/0034-7167-2020-0610.

6. Zhang Y, Gerdtham UG, Rydell H, Jarl J. Quantifying the Treatment Effect of Kidney Transplantation Relative to Dialysis on Survival Time: New Results Based on Propensity Score Weighting and Longitudinal Observational Data from Sweden. Int J Environ Res Public Health. 2020;17(19):7318. DOI: http://dx.doi.org/10.3390/ijerph17197318.

7. Chang CH, Fan PC, Kuo G, Lin YS, Tsai TY, Chang SW, Tian YC, Lee CC. Infection in Advanced Chronic Kidney Disease and Subsequent Adverse Outcomes after Dialysis Initiation: A Nationwide Cohort Study. Sci Rep. 2020;10(1):2938. DOI: http://dx.doi.org/10.1038/s41598020-59794-7.

8. Sousa SR, Galante NZ, Barbosa DA, Pestana JO. Incidence of infectious complications and their risk factors in the first year after renal transplantation. J Bras Nefrol. 2010;32(1):75-82.

9. Agrawal A, Ison MG, Danziger-Isakov L. Long-Term Infectious Complications of Kidney Transplantation. Clin J Am Soc Nephrol. 2021:CJN:15971020. DOI: http://dx.doi.org/10.2215/CJN.15971020.

10. van Delden C, Stampf S, Hirsch HH, Manuel O, Meylan P, Cusini A, et al. Swiss Transplant Cohort Study. Burden and Timeline of Infectious Diseases in the First Year After Solid Organ Transplantation in the Swiss Transplant Cohort Study. Clin Infect Dis. 2020;71(7):e159. DOI: http://dx.doi.org/10.1093/cid/ciz1113.

11. Freire MP, Song ATW, Oshiro ICV, Andraus W, D'Albuquerque LAC, Abdala E. Surgical site infection after liver transplantation in the era of multidrug-resistant bacteria: what new risks should be considered? Diagn Microbiol Infect Dis. 2021;99(1):115220. DOI: http://dx.doi. org/10.1016/j.diagmicrobio.2020.115220.

12. Wendt R, Nickel O, Botsch A, Lindner M, Bethge A, Marx K, et al. Low colonization rates with Multidrug-resistant Gram-negative bacteria in a German hospital-affiliated hemodialysis center. PLoS One. 2020;15(10):e0240314. DOI: http://dx.doi.org/10.1371/journal. pone.0240314.

13. Almeida Filho N, Barreto ML. Epidemiologia \& saúde: fundamentos, métodos e aplicações. 1st ed. São Paulo: Guanabara Koogan; 2014.

14. Thomas D. New techniques for the analysis of cohort studies. Epidemiol Rev. 1998;20(1):122-34. DOI: http://dx.doi.org/10.1093/ oxfordjournals.epirev.a017967.

15. Sandes-Freitas TV. Expanded donor criteria in kidney transplantation: a suitable option to increase the donor pool in Brazil? J Bras Nefrol. 2016;38(3):273-4.

16. Taminato M, Fram D, Pereira RRF, Sesso R, Belasco AGS, Pignatari AC, et al. Infection related to Klebsiella pneumoniae producing carbapenemase in renal transplant patients. Rev Bras Enferm. 2019;72(3):760-6. DOI: http://dx.doi.org/10.1590/0034-7167-2019-0009.

17. EJ, Sesso RC, Piveta V, Pestana JOM. Fatores que influenciam a sobrevida de transplantes renais com boa função renal ao final do 1 ano. J Bras Nefrol. 1998;20(1):10-7.

18. Ribeiro MNS, Santo FHDE, Simões BDS, Diniz CX, Bezerra HCA, Santos LD. Feelings, experiences and expectations of kidney transplant individuals and challenges for the nurse. Rev Bras Enferm. 2021;74(1):e20200392. DOI: http://dx.doi.org/10.1590/0034-7167-2020-0392.

19. Studart RMB, Nunes AC, Queiroz RM. Clinical and Immunological Assessment of Renal Transplant Recipients. Rev Fund Care Online. 2019;11(5):1202-7. DOI: http://dx.doi.org/10.9789/2175-5361.2019.v11i5.1202-1207.

20. Conte C, Secchi A. Post-transplantation diabetes in kidney transplant recipients: an update on management and prevention. Acta Diabetol. 2018;55(8):763-79. DOI: http://dx.doi.org/10.1007/s00592-018-1137-8. 
21. Alevizakos M, Nasioudis D, Mylonakis E. Urinary tract infections caused by ESBL-producing Enterobacteriaceae in renal transplant recipients: A systematic review and meta-analysis. Transpl Infect Dis. 2017;19(6). DOI: http://dx.doi.org/10.1111/tid.12759.

22. Halaji M, Shahidi S, Atapour A, Ataei B, Feizi A, Havaei SA. Characterization of Extended-Spectrum $\beta$-Lactamase-Producing Uropathogenic Escherichia coli Among Iranian Kidney Transplant Patients. Infect Drug Resist. 2020;13:1429-37.

23. Espinar MJ, Miranda IM, Costa-de-Oliveira S, Rocha R, Rodrigues AG, Pina-Vaz C. Urinary Tract Infections in Kidney Transplant Patients Due to Escherichia coli and Klebsiella pneumoniae-Producing Extended-Spectrum $\beta$-Lactamases: Risk Factors and Molecular Epidemiology. PLoS One. 2015;10(8):e0134737. DOI: http://dx.doi.org/10.1371/journal.pone.0134737.

24. Abo BJ, Kiel M, Görlich D, Schütte-Nütgen K, Witten A, Pavenstädt H, et al. Phenotypic and Genotypic Characterization of Escherichia coli Causing Urinary Tract Infections in Kidney-Transplanted Patients. J Clin Med. 2019;8(7):988. DOI: http://dx.doi.org/10.3390/jcm8070988.

25. Hospital do Rim - Fundação Oswaldo Ramos. Protocolo De Imunossupressao - Conducao Ambulatorial - Esquemas de imunossupressão. São Paulo: Hospital do Rim - Fundação Oswaldo Ramos; 2019.

26. Bicalho PR, Requião-Moura LR, Arruda ÉF, Mello L, Bertocchi APF, Naka EL,et al. Long-Term Outcomes among Kidney Transplant Recipients and after Graft Failure: A Single-Center Cohort Study in Brazil. Biomed Res Int. 2019;2019:7105084. DOI: http://dx.doi. org/10.1155/2019/7105084. 